\title{
Polyphasic Characterisation of Non-Starter Lactic Acid Bacteria from Algerian Raw Camel's Milk and Their Technological Aptitudes
}

\author{
Yasmine Saidi ${ }^{1 \varsigma} \oplus$, Beatriz \\ del $\operatorname{Rio}^{25} \odot$, Djamel Eddine \\ Senouci ${ }^{1} \oplus$, Begoña \\ Redruello² ${ }^{2}$, Beatriz \\ Martinez ${ }^{2} \bullet$, Victor Ladero ${ }^{2 *} \odot$, \\ Mebrouk Kihal' $\odot$ and Miguel \\ A. Alvarez ${ }^{2} \odot$
}

${ }^{1}$ Applied Microbiology Laboratory, Department of Biology, Faculty of Nature and Life Sciences, University of Oran, 31000 Oran, Algeria

2Dairy Research Institute (IPLA-

(SIC), Paseo Rio Linares s/n, 33300

Villaviciosa, Spain

Received: 10 December 2019

Accepted: 31 July 2020

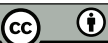

\footnotetext{
${ }^{*}$ Corresponding author:

E-mail: ladero@ipla.csic.es

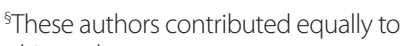
this work
}

\section{SUMMARY}

Research background. Consumption of spontaneously fermented camel's milk is common in Algeria, making it a feasible source of diverse lactic acid bacteria (LAB) with the potential to be used as adjunct cultures to improve quality and safety of fermented dairy products.

Experimental approach. Twelve raw camel's milk samples were used as a source of indigenous $L A B$, which were further characterised by examining 39 phenotypic traits with technological relevance.

Results and conclusions. Thirty-five non-starter LAB (NSLAB) were isolated from $12 \mathrm{Al}$ gerian raw camel's milk samples and they were microbiologically, biochemically and genetically characterised. Some isolates showed proteolytic activity, acidifying capacity, the ability to use citrate, and to produce dextran and acetoin. Ethanol, acetaldehyde, methyl acetate, acetoin and acetic acid were the major volatile compounds detected. Cluster analysis performed using the unweighted group with arithmetic average (UPGMA) method, and based on the thirty-nine phenotypic characteristics investigated, reflected the microbial diversity that can be found in raw camel's milk.

Novelty and scientific contribution. The isolated strains, from a non-typical source, showed interesting technological traits to be considered as potential adjunct cultures. Cluster analysis based on the examined phenotypic characteristics proved to be a useful tool for the typification of isolates when no genetic information is available. These findings may be of use towards an industrialised production of camel's milk dairy products.

Key words: camel's milk, lactic acid bacteria, molecular identification, acidifying capacity, proteolytic activity, biogenic amines

\section{INTRODUCTION}

Extensive camel (Camelus dromedarius) breeding remains the main agricultural activity of farmers in the arid regions of southern Algeria. Camels are a good source of meat and milk. A female camel may produce from 4 to $14 \mathrm{~kg}$, and sometimes up to $19 \mathrm{~kg}$ of milk per day (1). It is mainly consumed by the local population in the form of raw milk or as traditional fermented milk. The latter is considered a beverage with interesting health-promoting properties. Fermentation is spontaneous; thus, camel's milk could be a source of LAB (2) useful in the more industrialised production of high-quality camel's milk products. Such strains might be better adapted to the camel's milk environment than the LAB commonly used in the dairy industry, which originate from cow's or goat's milk. The isolation and characterisation of indigenous microbial diversity is a key step in order to design tailored starter cultures for artisanal/traditional fermented food that increase the safety and quality of such highly appreciated foodstuffs (3).

Non-starter $L A B$ (NSLAB) make an important contribution to the final organoleptic characteristics of fermented milk products; the probiotic properties of some may also be of health benefit (4). NSLAB characterisation mainly focuses on their technological properties, such as their proteolytic activity, and their capacity to produce antimicrobial compounds, flavour compounds, and texture components (5). However, their production of toxic compounds, 
such as biogenic amines, needs to be eliminated $(6,7)$. Biogenic amines are low-molecular-mass, nitrogenous, basic organic compounds mainly synthesised via the decarboxylation of certain amino acids. Despite the important functions they have in virtually all living organisms, they can accumulate at high concentrations in certain foods, the ingestion of which can be dangerous (8). The most important bioactive amines in dairy products are histamine, tyramine, putrescine and cadaverine (8), while the main bioactive amine producers are lactobacilli, lactococci and enterococci (8).

The present work aims to identify, characterise and typify the cultivable NSLAB isolated from raw camel's milk produced in the western and southwestern Algeria. In order to identify suitable candidates for use as potential adjunct cultures in the manufacture of camel's milk dairy products, isolates were examined for their technological characteristics and their production of bioactive amines.

\section{MATERIALS AND METHODS}

\section{Milk sample collection}

Twelve samples (of about $200 \mathrm{~mL}$ each) of camel's milk were collected from eight areas of western and southwestern Algeria (Abadla, Adrar, Bechar, Ghardaia, Mecheria, Oran, Saida and Tindouf), i.e. areas with large camel stocks. Milk was obtained directly from the udder of lactating camels. Before collection, the udders were cleaned with sterile warm water. All samples were securely capped, labelled with permanent markers and transported in a cool box at $<4^{\circ} \mathrm{C}$ to the Applied Microbiology Laboratory, University Oran 1 Ahmed Ben Bella (Oran, Algeria). Classical microbiological analyses were performed upon reception. All chemicals and broths, unless stated otherwise, were purchased from VWR (Barcelona, Spain).

\section{$\angle A B$ isolation and growth conditions}

Volumes of $10 \mathrm{~mL}$ of camel's milk were homogenized with $90 \mathrm{~mL}$ of $0.1 \%(\mathrm{~m} / \mathrm{V})$ sterile peptone water (Oxoid, Basingstoke, Hampshire, UK) to obtain a 1:10 dilution. Tenfold dilutions were then made with the same sterile $0.1 \%$ peptone water and 0.1 $\mathrm{mL}$ of each dilution plated in duplicate on M17 and MRS agar (Oxoid). After air drying, a second layer of the corresponding medium was poured to generate microaerophilic conditions. For fully anaerobic conditions, the plates were introduced as required into an airtight container with a flame to remove the remaining oxygen. Incubations on M17 were performed at 30 and $45^{\circ} \mathrm{C}$ under microaerophilic conditions, while incubations on MRS were performed at 30 and $45^{\circ} \mathrm{C}$, at $\mathrm{pH}=5.4$ and 9.6, with 4 and $6.5 \% \mathrm{NaCl}$, under microaerophilic and anaerobic conditions. Isolated colonies were streaked twice to ensure they represented pure cultures. Working cultures were kept on MRS or M17 agar slants at $4{ }^{\circ} \mathrm{C}$ and streaked every 4 weeks. For long-term storage, stock cultures of the isolates were stored at $-20{ }^{\circ} \mathrm{C}$ in $30 \%(\mathrm{~V} / \mathrm{V})$ glycerol with $70 \%(\mathrm{~V} / \mathrm{V})$ skimmed cow's milk (Candia, Oran, Algeria).

\section{Phenotypic characterisation of the isolates}

All isolates were phenotypically assigned to genera on the basis of colony appearance, cell morphology (assessed by microscopy; Zeiss, Göttingen, Germany), Gram staining, catalase activity, spore formation, $\mathrm{CO}_{2}$ production from glucose in $\mathrm{M} 17$ and MRS broth containing inverted Durham tubes (9), the hydrolysis of arginine on M16BCP medium (10), growth at 15 and $45^{\circ} \mathrm{C}$, tolerance to 4 and $6.5 \% \mathrm{NaCl}$, and tolerance to $\mathrm{pH}=9.6$.

\section{Molecular identification of the isolates}

Total genomic DNA from the isolates was extracted using the GenElute Bacterial Genomic DNA Kit (Sigma-Aldrich, Merck, Madrid, Spain), following the manufacturer's recommendations. The purified DNA was then stored at $4{ }^{\circ} \mathrm{C}$ until analysis. Purified genomic DNA was used as a template in polymerase chain reaction (PCR) amplification of a fragment of the 16S rRNA gene in a T100 Thermal Cycler (Bio-Rad, Madrid, Spain). For this, total DNA $(1 \mu \mathrm{L})$ was used in a final volume of $25 \mu \mathrm{L}$ containing $2.5 \mu \mathrm{L}$ buffer $10 \times, 2.5 \mu \mathrm{L}$ deoxyribonucleotide triphosphate (dNTPs) 2 mM, $0.2 \mu \mathrm{L}$ DreamTaq DNA polymerase (Thermo Fisher Scientific, Madrid, Spain), $1 \mu \mathrm{L}$ of the universal prokaryotic primer S-D-Bact0008-a-S-20 (27F) (5'-AGAGTTTGATCCTGGCTCAG-3'), and $1 \mu \mathrm{L}$ of the universal prokaryotic primer S-*-Univ1492R-b-A-21 (1492R) (5'-GGTTACCTTGTTACGACTT-3') (11). The PCR conditions were as follows: one cycle at $95^{\circ} \mathrm{C}$ for $4 \mathrm{~min}, 35$ cycles at $94^{\circ} \mathrm{C}$ for $30 \mathrm{~s}, 50$ ${ }^{\circ} \mathrm{C}$ for $30 \mathrm{~s}$ and $72{ }^{\circ} \mathrm{C}$ for $1.5 \mathrm{~min}$, and a final extension step at $72{ }^{\circ} \mathrm{C}$ for $7 \mathrm{~min}$ (12). Amplicons were purified using the ATP ${ }^{\mathrm{TM}}$ Gel PCR Fragment DNA Kit (ATP Biotech Inc., Taipei, Taiwan) and sequenced using the 27F primer from Macrogen (Amsterdam, The Netherlands). The obtained sequences were compared with those in the GenBank database using BLAST suite software (13). Partial sequencing of the superoxide dismutase gene (sod) from Enterococcus isolates identified them as either Enterococcus durans, Enterococcus hirae or Enterococcus faecium. Total DNA was used as a template for PCR amplification of an internal fragment of sod. The PCR reaction was performed as described above but using the degenerated primers sodAd1 (5'-CCITAYICITAYGAYGCIYTIGARCC-3') and sodAd2 (5'-ARRTARTAIGCRTGYTCCCAIACRTC-3') (14). The PCR reaction conditions included a denaturation step (3 $\mathrm{min}$ at $95^{\circ} \mathrm{C}$ ), followed by 35 cycles of amplification ( $30 \mathrm{~s}$ of denaturation at $95^{\circ} \mathrm{C}, 30 \mathrm{~s}$ of annealing at $42^{\circ} \mathrm{C}, 90 \mathrm{~s}$ of elongation at $\left.72^{\circ} \mathrm{C}\right)$, and a final extension step $\left(7 \mathrm{~min}\right.$ at $\left.72^{\circ} \mathrm{C}\right)$. Amplicons were purified using the ATP ${ }^{\mathrm{TM}}$ Gel PCR Fragment DNA Kit and sequenced using the primer sodAd1 from Macrogen. The obtained sequences were compared with those in the GenBank database using BLAST software (13).

\section{Technological characterisation}

Technological characterisation of the isolated lactic acid bacteria has been assessed by the determination of acidifying capacity, and the proteolytic activity, the citrate utilisation, the acetoin, dextran, volatile compounds and antimicrobial 
substance production. The following assays were performed in triplicate unless otherwise stated.

\section{Determination of acidifying capacity}

Overnight cultures of the isolates were used to inoculate ultrahigh temperature (UHT) skimmed cow's milk at $1 \%(V / V)$, incubated at $\left.30^{\circ} \mathrm{C}\right)$. The change in the $\mathrm{pH}$ was recorded every 30 min for $18 \mathrm{~h}$ with a $\mathrm{pH}$ meter (Orion ${ }^{\mathrm{TM}}$ Versa Star $^{\mathrm{TM}}$, Thermo Fischer Scientific, Madrid, Spain); only values after 6 and $18 \mathrm{~h}$ are shown. Milk clotting was assessed at the end of fermentation.

\section{Determination of proteolytic activity}

The proteolytic activity of the isolates was examined by a qualitative method on plate count agar (PCA; Oxoid) supplemented with $2 \%$ UHT skimmed cow's milk (Oxoid). Isolated cultures were streaked on these plates and incubated at $30^{\circ} \mathrm{C}$ for $24 \mathrm{~h}$. A clear zone around the colonies indicated proteolytic activity. In addition, the proteolytic activity of the isolates was quantitatively determined using the o-phthaldialdehyde (OPA) method (12). Briefly, after incubation of the strains in the same type of skimmed cow's milk at $30^{\circ} \mathrm{C}$ for 24 $\mathrm{h}$, the protein fraction was precipitated out of 1- $\mathrm{mL}$ samples by adding $2 \mathrm{~mL}$ of $0.75 \mathrm{M}$ trichloroacetic acid (Sigma-Aldrich, Merck) and $0.2 \mathrm{~mL}$ of water. The mixtures were then vortexed for $2 \mathrm{~min}$ and filtered through a 0.20 - $\mu \mathrm{m}$ pore diameter membrane (Millipore, Bedford, MA, USA). The OPA reagent (Sigma-Aldrich, Merck) was added to the filtrates and the absorbance was measured at $340 \mathrm{~nm}$ using a Benchmark Plus microplate spectrophotometer (Bio-Rad, Hercules, CA, USA). Results were expressed as glycine (Gly) using an appropriate calibration curve (concentration range 0.1-10 mM). Positive controls were established by inoculating UHT skimmed cow's milk with Lactococcus lactis NCDO $604^{\top}$ and Lc. lactis SH4109 (15) strains known for their strong proteolytic activity. Non-inoculated UHT skimmed milk samples were incubated under the same conditions as negative controls.

\section{Citrate utilisation}

Kempler and McKay (KMK) culture medium containing iron(III) citrate and potassium hexacyanoferrate(III) (Biochem Chemopharma, Cosne-Cours-sur-Loire, France) was used to assess the capacity of the isolates to utilise citrate (16). Cultures that turned blue after incubation at 30 or $45^{\circ} \mathrm{C}$ for 24 $48 \mathrm{~h}$ were considered able to use citrate.

\section{Production of acetoin}

Acetoin production was tested by inoculating the isolates into $10 \mathrm{~mL}$ of Clark and Lubs medium, incubating at 30 and $45^{\circ} \mathrm{C}$ for $24 \mathrm{~h}$, and testing via the Vosges-Proskaur (VP) reaction by adding to $1 \mathrm{~mL}$ of the culture $0.5 \mathrm{~mL}$ of the VP I reagent (prepared by adding a-naphtol to absolute alcohol to a volume fraction of $6 \%$ ) and $0.5 \mathrm{~mL}$ of the VP II reagent (a 16 $\%$ solution of $\mathrm{NaOH}$ prepared in distilled water). The reaction tubes were then agitated for 1 min. After a 10-minute rest, the presence of a pink ring on the surface of the culture was deemed to indicate the production of acetoin.

\section{Production of dextran}

Dextran production was investigated on Mayeux, Sandine and Elliker (MSE) agar medium rich in sucrose. After an incubation at 30 or $45^{\circ} \mathrm{C}$ for $24-48 \mathrm{~h}$, viscous colonies were deemed to be those of dextran producers.

\section{Production of volatile compounds}

The production of volatile compounds was assessed by inoculating UHT skimmed cow's milk with overnight cultures at $1 \%(\mathrm{~V} / \mathrm{V})$. After $24 \mathrm{~h}$ of incubation at $30^{\circ} \mathrm{C}$, the volatile compounds were quantified using a headspace gas chromatograph (Agilent Technologies, Wilmington DE, USA) connected to a mass spectrophotometer detector (HS/GC/MS) equipped with a DB-WAXetr capillary column (60 mm×0.25 $\mathrm{mm} \times 0.25 \mu \mathrm{m}$, Agilent). Sample preparation and gas chromatographic separation were performed as previously described (17). Compounds were quantified as the normalized value of their chromatogram peak area using cyclohexanone $(3.6 \mu \mathrm{g} / \mathrm{mL})$ as an internal standard, which was given a value of 100 (12). Non-inoculated UHT skimmed cow's milk samples were incubated under the same conditions as negative controls. The difference between the values obtained for the sample and negative controls were calculated.

\section{Determination of the production of} antimicrobial substances

The antibacterial activity of the isolates was determined via well diffusion assays as reported by Schillinger and Lücke (18). Lactobacillus sakei CECT 906 ${ }^{\top}$, Lactococcus lactis ssp. cremoris MG1363, Listeria innocua CECT 910' ${ }^{\top}$ Micrococcus luteus NCIMB 8166, Streptococcus thermophilus LMD9 and S. thermophilus CNRZ 1066 were used as microbial indicators. Briefly, 45 $\mathrm{mL}$ of $1.2 \%$ agar medium at $45^{\circ} \mathrm{C}$ were vigorously mixed with $40 \mu \mathrm{L}$ of an overnight culture of each indicator and poured into Petri dishes. Supernatants from overnight cultures, in duplicate, of the tested strains were adjusted to $\mathrm{pH}=6.5-7.0$ with 0.1 $\mathrm{M} \mathrm{NaOH}$, and filtered through a $0.20-\mu \mathrm{m}$ pore diameter membrane (Millipore). Aliquots of $40 \mu \mathrm{L}$ of each supernatant were placed in a 4-mm well excavated in the agar plates. Antimicrobial activity was determined by measuring the diameter of the inhibition halo after $24 \mathrm{~h}$ of incubation under appropriate conditions. A halo diameter of $>8 \mathrm{~mm}$ was considered a positive result. The average result of duplicate assays is shown.

\section{Production of biogenic amines}

Biogenic amine production was measured in supernatants obtained after $48 \mathrm{~h}$ of incubation of the strains in 10 $\mathrm{mL}$ of MRS broth supplemented with either $1 \mathrm{mM}$ tyrosine, 1 $\mathrm{mM}$ histidine, $1 \mathrm{mM}$ ornithine, $1 \mathrm{mM}$ agmatine (ornithine and 
agmatine are precursors of putrescine via different pathways) or $1 \mathrm{mM}$ lysine (all from Sigma-Aldrich, Merck). Tyramine, histamine, putrescine and cadaverine were detected as previously described (7). Briefly, $100 \mu \mathrm{L}$ of supernatant, obtained after centrifugation of the cultures at $3000 \times g$ for $10 \mathrm{~min}(5424$ benchtop centrifuge; Eppendorf, Hamburg, Germany), were derivatised with diethyl ethoxymethylenemalonate (Sigma-Aldrich, Merck) following a previously described protocol (19). Derivatised samples were filtered through a 0.2- $\mu \mathrm{m}$ pore diameter membrane and analysed by ultrahigh performance liquid chromatography (UHPLC) using a Waters H-Class ACQUITY UPLC apparatus with a UV detector (Waters, Milford, MA, USA) controlled by Empower v. 2.0 software (20) under the conditions described by Redruello et al. (19).

\section{Cluster analysis}

The relationships among isolates were examined by cluster analysis using the unweighted group with arithmetic average (UPGMA) method, and based on their physiological (production of $\mathrm{CO}_{2}$, hydrolysis of arginine, growth at $45^{\circ} \mathrm{C}, \mathrm{pH}=5.4$ and 9.6, tolerance of 4 and $6.5 \% \mathrm{NaCl}$ ), technological (reduction of $\mathrm{pH}$, clotting of milk, proteolytic activity, ability to utilise citrate, production of dextran and acetoin, production of volatile compounds and antimicrobial activity) and safety (biogenic amine production) traits. A dendrogram was constructed to reflect inter- and intraspecies differences. Analyses were performed using the Dendro UPGMA server (21). The final tree was generated on the iTOL webpage (22).

\section{RESULTS AND DISCUSSION}

\section{Phenotypic identification of strains}

All 35 isolates were Gram-positive, catalase-negative and non-spore forming, and thus, considered to be LAB (Table 1). The morphological distribution (microscopic observation) indicated 21 isolates (60\%) to be ovococci, 7 (20\%) coccobacilli, and another 7 (20\%) rods.

The isolates of ovococci were homofermentative and able to grow at $45^{\circ} \mathrm{C}$ in the presence of $6.5 \%$ of $\mathrm{NaCl}$, and even at $\mathrm{pH}=9.6$ (Table 1), suggesting they belonged to Enterococcus genus. Since none of the coccobacilli were able to hydrolyze arginine, they were assigned to the genus Leuconostoc (Table 1) $(23,24)$. All 7 rod-shaped isolates were presumptively classified within Lactobacillus genus.

\section{Results of molecular identification of isolates}

Once phenotypically characterised, all 35 isolates were identified at the species level by sequencing and inspection of the $16 \mathrm{~S}$ rRNA gene. For isolates belonging to Enterococcus, the sod gene was also sequenced and compared. The results of the molecular identification agreed with those of the phenotypic identification at the genus level. Table 1 shows that the 35 isolates belonged to four species. The most common was Enterococcus faecium (54\%), followed by Leuconostoc mesenteroides and Lactobacillus rhamnosus (20\% each), and then Enterococcus hirae (6 \%). E. faecium and E. hirae have been frequently isolated from raw milk and dairy products (25-27). The presence of enterococci has for long been considered the result of poor hygiene during milking or handling (2), but these bacteria can be members of the normal microbiota of these products (28). Indeed, they play an important role in the ripening of several types of cheese via their lipolytic and proteolytic activities, and they contribute to flavour via the production of certain aromatic compounds (29).

\section{Technological characterisation of the isolates}

\section{Acidifying capacity of isolated strains}

The ability of the strains to produce acid in commercial skimmed cow's milk was assessed by measuring the $\mathrm{pH}$ of the medium over $18 \mathrm{~h}$ (Table 2). All the isolates were slow acidifiers; none reduced the $\mathrm{pH}$ by more than 1 unit (Lactobacillus between 0.18 and 0.35 , Leuconostoc 0.17 and 0.69 , and Enterococcus isolates $0.24-0.78$ ) in the first $6 \mathrm{~h}$. After $18 \mathrm{~h}$, the final $\mathrm{pH}$ varied from 6.14 by $L n$. mesenteroides isolate LEY3 to 4.71 by $E$. hirae isolate LMA18. The $L b$. rhamnosus isolates showed medium acidifying capacity and could be used as part of a mixed starter culture (30). Only four isolates (Lb. rhamnosus LEY15, E. hirae LMA16 and LMA18 and E. faecium LMA9) partially clotted the milk at the bottom of the tube after $18 \mathrm{~h}$ (Table 2). This low acidification activity of all the isolates indicates that they must be used in combination with strong acidifying starter cultures, for example of the species $L c$. lactis, for the elaboration of dairy products.

\section{Proteolytic activity of isolated strains}

Proteolytic activity against casein is a property of interest for any strain to be used as an adjunct culture (31). This ability of $L A B$ strains to grow and develop in milk is essential (32). In the present work, proteolytic activity was examined qualitatively via growth on PCA supplemented with skimmed cow's milk, and quantitatively via the OPA assay. All the tested isolates showed a clarification halo on the supplemented PCA plates and were therefore considered proteolytic (data not shown). The OPA assay was more discriminating, revealing inter- and intra-species differences in proteolytic activity between the isolates (Fig. 1). All the lactobacilli had a proteolytic activity expressed in equivalents of glycinic acid (Gly) to about $1.00 \mathrm{mM}$, with isolate LEY14 showing the weakest activity of $(0.70 \pm 0.05)$ $\mathrm{mM}$ and isolate LEY15 the strongest of $(1.3 \pm 0.1) \mathrm{mM}$. E. hirae isolates LMA16 and LMA18 showed similar activity of (0.9 \pm 0.3$)$ and $(0.9 \pm 0.2) \mathrm{mM}$, respectively. Among the E. faecium isolates, isolate LMA17 had the maximum activity, and the isolate LMA5 minimum of $(1.2 \pm 0.3)$ and $(0.67 \pm 0.08) \mathrm{mM}$, respectively (denoting intraspecies variation). Intraspecies variation was also found among the Leuconostoc isolates. Isolate LEY10 showed notable activity with an equivalent of $(1.2 \pm 0.4) \mathrm{mM}$; in contrast, none of the other Leuconostoc isolates exceeded $0.79 \mathrm{mM}$. As 
Table 1. Phenotypic and genotypic identification of lactic acid bacteria isolated from Algerian camel's milk

\begin{tabular}{|c|c|c|c|c|c|c|c|c|}
\hline \multirow{2}{*}{ Isolate } & \multirow{2}{*}{$\begin{array}{l}\text { Species (based on molecular } \\
\text { identification) }\end{array}$} & \multirow{2}{*}{$\begin{array}{l}\mathrm{CO}_{2} \\
\text { production }\end{array}$} & \multirow{2}{*}{$\begin{array}{l}\text { Arginine } \\
\text { hydrolysis }\end{array}$} & \multicolumn{5}{|c|}{ Growth at } \\
\hline & & & & $t=45^{\circ} \mathrm{C}$ & $\mathrm{pH}=5.4$ & $\mathrm{pH}=9.6$ & $w(\mathrm{NaCl})=4 \%$ & $w(\mathrm{NaCl})=6.5 \%$ \\
\hline LEY1 & Leuconostoc mesenteroides & + & - & - & - & - & + & - \\
\hline LEY2 & Leuconostoc mesenteroides & + & - & - & - & - & + & - \\
\hline LEY3 & Leuconostoc mesenteroides & + & - & - & - & - & + & - \\
\hline LEY4 & Leuconostoc mesenteroides & + & - & - & - & - & + & - \\
\hline LEY5 & Leuconostoc mesenteroides & + & - & - & - & - & + & - \\
\hline LEY9 & Leuconostoc mesenteroides & + & - & - & - & - & + & - \\
\hline LEY10 & Leuconostoc mesenteroides & + & - & - & - & - & + & - \\
\hline LEY14 & Lactobacillus rhamnosus & - & + & + & + & - & + & - \\
\hline LEY15 & Lactobacillus rhamnosus & - & + & + & + & - & + & - \\
\hline LEY16 & Lactobacillus rhamnosus & - & + & + & + & - & + & - \\
\hline LEY17 & Lactobacillus rhamnosus & - & + & + & + & - & + & - \\
\hline LEY18 & Lactobacillus rhamnosus & - & + & + & + & - & + & - \\
\hline LEY19 & Lactobacillus rhamnosus & - & + & + & + & - & + & - \\
\hline LEY20 & Lactobacillus rhamnosus & - & + & + & + & - & + & - \\
\hline LMA16 & Enterococcus hirae & - & + & + & - & + & + & + \\
\hline LMA18 & Enterococcus hirae & - & + & + & - & + & + & + \\
\hline LMA1 & Enterococcus faecium & - & + & + & - & + & + & + \\
\hline LMA2 & Enterococcus faecium & - & + & + & - & + & + & + \\
\hline LMA3 & Enterococcus faecium & - & + & + & - & + & + & + \\
\hline LMA4 & Enterococcus faecium & - & + & + & - & + & + & + \\
\hline LMA5 & Enterococcus faecium & - & + & + & - & + & + & + \\
\hline LMA6 & Enterococcus faecium & - & + & + & - & + & + & + \\
\hline LMA7 & Enterococcus faecium & - & + & + & - & + & + & + \\
\hline LMA8 & Enterococcus faecium & - & + & + & - & + & + & + \\
\hline LMA9 & Enterococcus faecium & - & + & + & - & + & + & + \\
\hline LMA10 & Enterococcus faecium & - & + & + & - & + & + & + \\
\hline LMA11 & Enterococcus faecium & - & + & + & - & + & + & + \\
\hline LMA12 & Enterococcus faecium & - & + & + & - & + & + & + \\
\hline LMA13 & Enterococcus faecium & - & + & + & - & + & + & + \\
\hline LMA14 & Enterococcus faecium & - & + & + & - & + & + & + \\
\hline LMA15 & Enterococcus faecium & - & + & + & - & + & + & + \\
\hline LMA17 & Enterococcus faecium & - & + & + & - & + & + & + \\
\hline LMA19 & Enterococcus faecium & - & + & + & - & + & + & + \\
\hline LMA20 & Enterococcus faecium & - & + & + & - & + & + & + \\
\hline LMA21 & Enterococcus faecium & - & + & + & - & + & + & + \\
\hline
\end{tabular}

other authors report, milk proteolytic capacity appears to vary both within and among species isolated from natural sources $(33,34)$. This ability is therefore strain-dependent $(28,35,36)$. Interestingly, some isolates, such as Lb. rhamnosus LEY15 and Ln. mesenteroides LEY10, showed good proteolytic activity, suggesting they might have practical applications and be responsible for releasing peptides and amino acids responsible for the product texture and aroma $(37,38)$. Some amino acids are involved in the production of aroma compounds, serving either directly or indirectly as precursors of aldehydes, acids, alcohols and esters (35), and thus contributing to the sensory profile of the end product (5).
Analysis of the citrate utilisation capability

The capacity of LAB to utilise the citrate present in milk is a desirable technological trait; its metabolism results in an excess of pyruvate that can be converted via a-acetolactate to diacetyl, acetoin and 2,3-butanediol - important flavour and aroma components of certain fermented dairy products (39). Table 3 shows that all the isolates of lactobacilli were positive for citrate utilisation, and in the case of Leuconostoc, only isolate LEY10 was unable to use it. The two $E$. hirae isolates were also able to utilise citrate, as were all but three E. faecium isolates (LMA1, LMA5 and LMA8) (Table 3). 
Table 2. Acidification kinetics of the isolates from raw camel's milk in UHT skimmed cow's milk

\begin{tabular}{|c|c|c|c|}
\hline \multirow{4}{*}{ Species/Strain } & \multicolumn{3}{|c|}{ Incubation in UHT skimmed milk* } \\
\hline & \multicolumn{3}{|c|}{$t / \mathrm{h}$} \\
\hline & 6 & 18 & 18 \\
\hline & $\mathrm{pH}$ & $\mathrm{pH}$ & Milk clotting \\
\hline \multicolumn{4}{|l|}{ Ln. mesenteroides } \\
\hline LEY1 & $6.3 \pm 0.3$ & $5.2 \pm 0.5$ & - \\
\hline LEY2 & $6.1 \pm 0.1$ & $5.3 \pm 0.3$ & - \\
\hline LEY3 & $6.5 \pm 0.1$ & $6.1 \pm 0.1$ & - \\
\hline LEY4 & $6.37 \pm 0.08$ & $6.0 \pm 0.1$ & - \\
\hline LEY5 & $6.4 \pm 0.3$ & $5.4 \pm 0.2$ & - \\
\hline LEY9 & $6.50 \pm 0.06$ & $5.6 \pm 0.2$ & - \\
\hline LEY10 & $6.4 \pm 0.2$ & $5.9 \pm 0.5$ & - \\
\hline \multicolumn{4}{|l|}{ Lb. rhamnosus } \\
\hline LEY14 & $6.5 \pm 0.2$ & $5.3 \pm 0.3$ & - \\
\hline LEY15 & $6.3 \pm 0.1$ & $4.9 \pm 0.4$ & $+/-$ \\
\hline LEY16 & $6.6 \pm 0.1$ & $5.6 \pm 0.5$ & - \\
\hline LEY17 & $6.6 \pm 0.2$ & $5.0 \pm 0.5$ & - \\
\hline LEY18 & $6.6 \pm 0.2$ & $4.8 \pm 0.2$ & - \\
\hline LEY19 & $6.7 \pm 0.2$ & $5.7 \pm 0.5$ & - \\
\hline LEY20 & $6.5 \pm 0.1$ & $5.3 \pm 0.6$ & - \\
\hline \multicolumn{4}{|l|}{ E. hirae } \\
\hline LMA16 & $6.0 \pm 0.2$ & $4.98 \pm 0.09$ & $+/-$ \\
\hline LMA18 & $6.04 \pm 0.05$ & $4.7 \pm 0.2$ & $+/-$ \\
\hline \multicolumn{4}{|l|}{ E. faecium } \\
\hline LMA1 & $6.3 \pm 0.1$ & $5.72 \pm 0.04$ & - \\
\hline LMA2 & $6.44 \pm 0.08$ & $5.6 \pm 0.5$ & - \\
\hline LMA3 & $6.3 \pm 01$ & $5.6 \pm 0.3$ & - \\
\hline LMA4 & $6.3 \pm 0.3$ & $5.6 \pm 0.3$ & - \\
\hline LMA5 & $6.3 \pm 0.2$ & $5.6 \pm 0.2$ & - \\
\hline LMA6 & $6.1 \pm 0.2$ & $5.2 \pm 0.5$ & - \\
\hline LMA7 & $6.2 \pm 0.3$ & $5.5 \pm 0.4$ & - \\
\hline LMA8 & $6.49 \pm 0.09$ & $5.8 \pm 0.2$ & - \\
\hline LMA9 & $6.3 \pm 0.3$ & $4.9 \pm 0.2$ & $+/-$ \\
\hline LMA10 & $6.6 \pm 0.2$ & $6.01 \pm 0.03$ & - \\
\hline LMA11 & $6.27 \pm 0.02$ & $5.6 \pm 0.3$ & - \\
\hline LMA12 & $6.3 \pm 0.2$ & $5.4 \pm 0.2$ & - \\
\hline LMA13 & $6.47 \pm 0.06$ & $5.3 \pm 0.4$ & - \\
\hline LMA14 & $6.3 \pm 0.2$ & $5.0 \pm 0.6$ & - \\
\hline LMA15 & $6.4 \pm 0.2$ & $5.1 \pm 0.3$ & - \\
\hline LMA17 & $6.4 \pm 0.2$ & $5.8 \pm 0.2$ & - \\
\hline LMA19 & $6.3 \pm 0.3$ & $5.1 \pm 0.4$ & - \\
\hline LMA20 & $6.3 \pm 0.2$ & $5.1 \pm 0.3$ & - \\
\hline LMA21 & $6.47 \pm 0.08$ & $5.34 \pm 0.09$ & - \\
\hline
\end{tabular}

*pH of non-inoculated UHT skimmed milk was $6.77,+/$ - partial clotting of milk at the bottom of the tube, UHT=ultra-high temperature

\section{Acetoin production capability of isolated strains}

Acetoin production, reflected by the presence of a pink ring in Clark and Lubs broth, was positive for all the tested enterococci, both the E. hirae and E. faecium isolates, all the Lb. rhamnosus isolates, and one Leuconostoc isolate (LEY10) (Table 3). Acetoin, which is produced via the catabolism of pyruvate, is responsible for the development of flavour and aroma. Enterococci and lactobacilli are the predominant genera able to produce it (34). Although Ln. mesenteroides LEY10, and E. faecium LMA1, LMA5 and LMA8 were unable to utilise

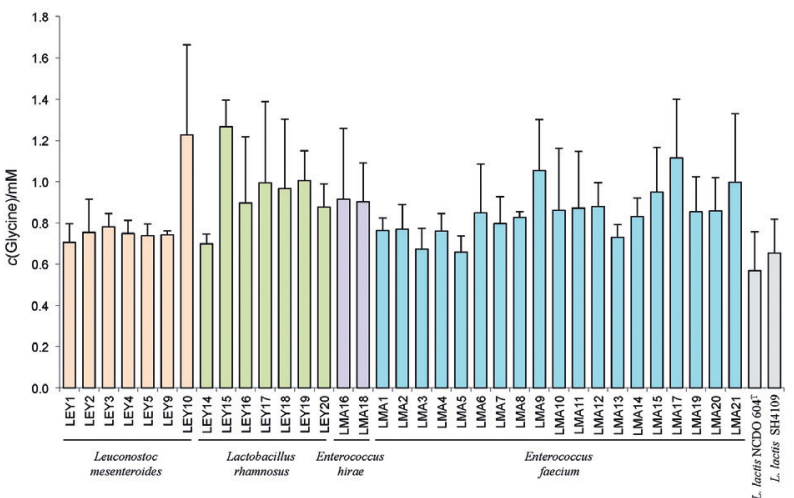

Fig. 1. Proteolytic activity of strains isolated from Algerian raw camel's milk as determined by the OPA assay. Proteolytic activity was recorded as $\mathrm{mmol}$ of glycine released after incubation in skimmed cow's milk at $30^{\circ} \mathrm{C}$ for $24 \mathrm{~h}$, using a glycine calibration curve. Lactococcus lactis NCDO $604^{\top}$ and Lactococcus lactis SH4109 strains were used as positive controls

Table 3. Citrate utilisation, and acetoin and dextran production by lactic acid bacteria isolated from Algerian camel's milk

\begin{tabular}{cccc} 
Species/strain & $\begin{array}{c}\text { Citrate } \\
\text { utilisation }\end{array}$ & $\begin{array}{c}\text { Acetoin } \\
\text { production }\end{array}$ & $\begin{array}{c}\text { Dextran } \\
\text { production }\end{array}$ \\
\hline Ln. mesenteroides & + & - & - \\
LEY1 & + & - & + \\
LEY2 & + & - & + \\
LEY3 & + & - & + \\
LEY4 & + & - & + \\
LEY5 & + & - & + \\
LEY9 & - & + & + \\
LEY10 & & & - \\
Lb. rhamn0sus & + & + & - \\
LEY14 & + & + & - \\
LEY15 & + & + & - \\
LEY16 & + & + & - \\
LEY17 & + & + & - \\
LEY18 & + & + & - \\
LEY19 & + & + & \\
LEY20 & & &
\end{tabular}

\begin{tabular}{|c|c|c|c|}
\hline \multicolumn{4}{|l|}{ E. hirae } \\
\hline LMA16 & + & + & - \\
\hline LMA18 & + & + & - \\
\hline \multicolumn{4}{|l|}{ E. faecium } \\
\hline LMA1 & - & + & - \\
\hline LMA2 & + & + & - \\
\hline LMA3 & + & + & - \\
\hline LMA4 & + & + & - \\
\hline LMA5 & - & + & - \\
\hline LMA6 & + & + & - \\
\hline LMA7 & + & + & - \\
\hline LMA8 & - & + & - \\
\hline LMA9 & + & + & - \\
\hline LMA10 & + & + & - \\
\hline LMA11 & + & + & - \\
\hline LMA12 & + & + & - \\
\hline LMA13 & + & + & - \\
\hline LMA14 & + & + & - \\
\hline LMA15 & + & + & - \\
\hline LMA17 & + & + & - \\
\hline LMA19 & + & + & - \\
\hline LMA20 & + & + & - \\
\hline LMA21 & + & + & - \\
\hline
\end{tabular}

- negative producer, + positive producer 
citrate (Table 3), they seem to catabolise some of the pyruvate, produced from sugar, into acetoin. All the isolates of lactobacilli and enterococci produced acetoin in this work, and may play an important role in the development of the distinctive organoleptic properties of fermented camel dairy products.

\section{Dextran production capability of isolated strains}

Table 3 shows that only the Leuconostoc isolates produced dextran, with the exception of isolate LEY1. This would suggest the latter to be $L n$. mesenteroides ssp. cremoris, a subspecies characterised by its non-production of this compound $(24,40)$. The dextran-producing ability of the Leuconostoc isolates makes them candidates for use in secondary starters; dextran improves the appearance, stability and rheological properties of dairy products (34) and has potential health benefits (immunogenic properties, protection against gastric ulcers, improvement of digestive transit, and hypocholesterolaemic, antiviral and antitumoral activity, etc.) (41).

\section{Analysis of the production of volatile compounds}

Flavour development in dairy products is essentially an enzymatic process performed (mainly) by microorganisms (35). Lactose fermentation leads to the formation of pyruvate that can be further metabolised to ethanol, diacetyl, acetoin and acetaldehyde (42). By producing volatile compounds, such as ethanol (important in kefir and koumiss), diacetyl (important in butter, buttermilk and cheese) and acetaldehyde (important in yoghurt and buttermilk) (5), LAB contribute to the typical flavours of different dairy products.

The production of volatile compounds was assessed by HS/GC/MS (17). Eighteen major compounds were identified (Table 4). Wide variation was observable in the diversity and quantity of volatile compounds produced by the different isolates. The most common compounds produced were ethanol, acetaldehyde, methyl acetate, acetoin and acetic acid. Acetaldehyde was produced by all the isolates except $L n$. mesenteroides LEY9 and LEY10. The production of acetoin in milk agreed with the results of the phenotypic test performed in Clark and Lubs medium. All the isolates of enterococci and lactobacilli gave positive results for both methods (HS/GC/ MS, and Clark and Lubs medium) (Table 3 and Table 4). However, while Ln. mesenteroides LEY10 was positive in the phenotypic test, no acetoin was detected when it was grown in milk, indicating the need for confirmatory testing. The production of diacetyl was detected in all Lb. rhamnosus isolates and E. hirae LMA16, but not in Ln. mesenteroides nor E. faecium isolates. The LAB producing the least volatile compounds were the Leuconostoc isolates. This might be explained by the fact that they grow poorly in milk and that they must be combined with acid-producing lactococci in order to act as flavour producers in mixed starters $(12,35,43)$. The ability of the Lb. rhamnosus isolates to produce flavour compounds such as diacetyl and acetoin suggests they could be used as adjunct cultures for developing cheese flavour (44).

\section{Antimicrobial substance production}

The potential production of antimicrobial substances by the isolates was tested against a variety of indicator strains, including several LAB species, since bacteriocins produced by Gram-positive bacteria are most commonly active against closely related bacteria. Table 5 shows that none of the isolates inhibited the growth of $S$. thermophilus CNRZ 1066. The indicator $L$ b. sakei CECT $906^{\top}$ was inhibited by all but one of the Lb. rhamnosus isolates, and by $42 \%$ of the E. faecium isolates, while M. luteus NCIMB 8166 was inhibited by $52 \%$ of the Leuconostoc isolates. Lc. lactis ssp. cremoris MG1363 was inhibited by $16 \%$ of the E. faecium isolates, L. innocua CECT $910^{\top}$ was inhibited by $42 \%$ of the E. faecium isolates, and S. thermophilus LMD9 by $26 \%$ of the E. faecium isolates. Wider inhibition activity was observed of the $E$. faecium isolates, which inhibited the growth of four of the indicator strains (all except S. thermophilus CNRZ1066 and M. luteus NCIMB 8166). E. faecium LMA5 showed the strongest activity. $L A B$ have a wide range of antimicrobial activities (45); $E$. faecium produces bacteriocin-like substances such as enterocins $A$ and $P$, while $L n$. mesenteroides produces leucocin (46). The present results agree with those reported in the literature, but further studies should test the capacity of these strains to inhibit the growth of pathogenic bacteria such as Listeria monocytogenes. They should also evaluate the potential of the isolates as adjunct cultures for improving food safety and shelf life.

\section{Biogenic amine production capability}

Dairy products accumulate the greatest diversity and quantity of biogenic amines (47). The consumption of food with elevated biogenic amine concentrations can lead to symptoms of intoxication. It should not, therefore, be allowed to accumulate to dangerous levels. One of the preventive measures that might be applied is the selection of strains for use in starter or co-starter cultures that are confirmed non-biogenic amine-producers (6). In the present work, the capacity to produce tyramine, histamine, putrescine and cadaverine was examined by UHPLC (19). Table 6 shows that all the E. faecium isolates produced tyramine. This is not surprising since tyramine production is a known species-dependent feature of E. faecium (48). The presence of biogenic amine-producing bacteria, such as enterococci, in the raw milk highlights the potential risk of allowing spontaneous fermentation, since as shown in this work, some harmful microorganisms could grow and accumulate toxic compounds (49). If E. faecium is to be used as an adjuvant culture, the balance between benefits and dangers must take into account the many factors that influence the accumulation of tyramine, such as the availability of tyrosine (due to casein proteolysis) and the presence of an acidic $\mathrm{pH}$ (6). Moreover, if a biogenic amine-producing strain also produces an antimicrobial substance, as is the case of $E$. faecium LMA5, it could dominate the microbiota and the risk of tyramine accumulation would be increased. 


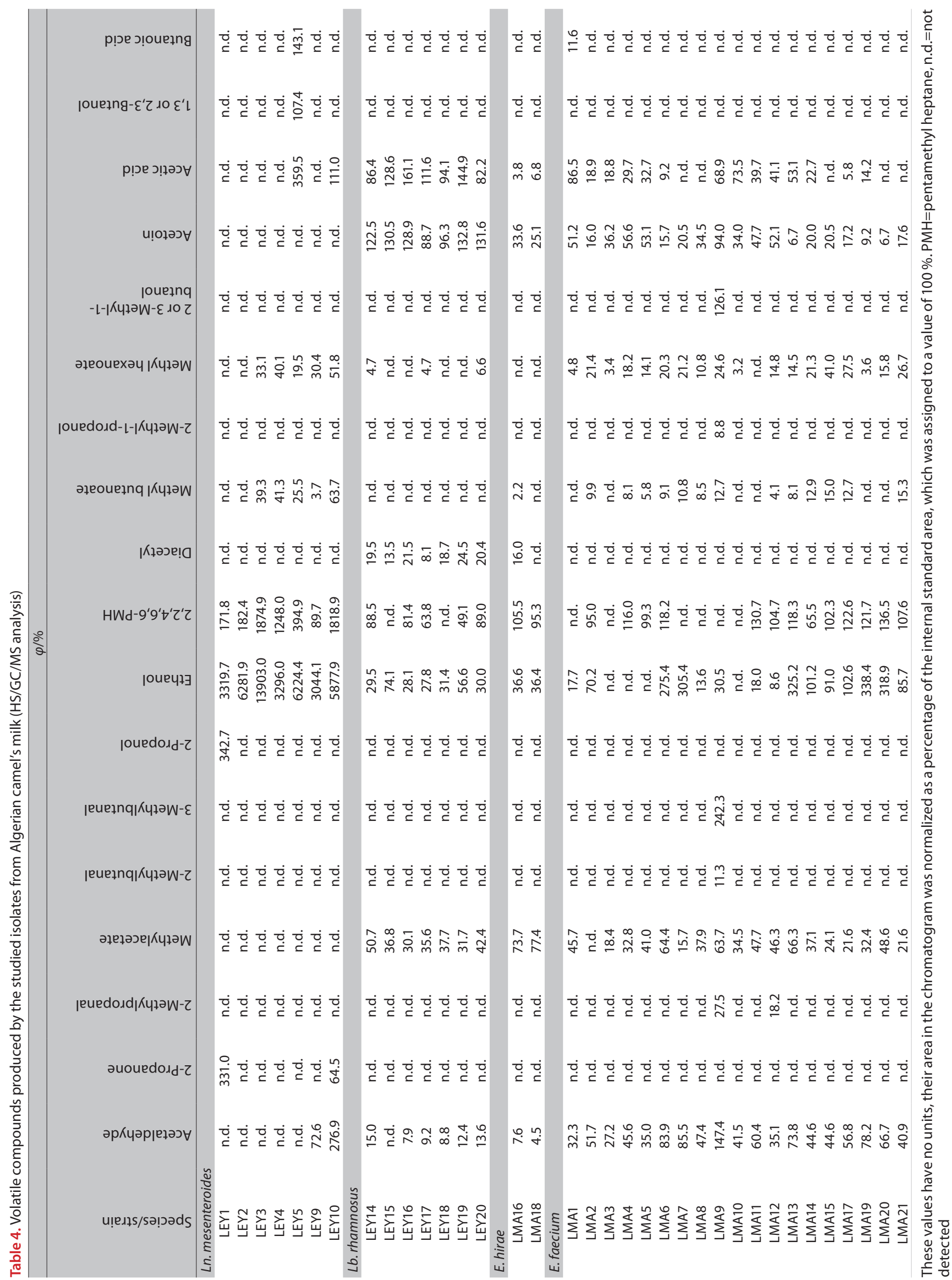


Table 5. Antimicrobial activity expressed as the diameter of the inhibition halo

\begin{tabular}{|c|c|c|c|c|c|c|}
\hline \multicolumn{7}{|c|}{$d$ (inhibition halo)/mm } \\
\hline 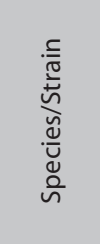 & 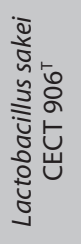 & 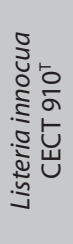 & 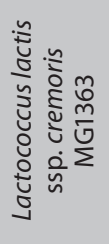 & 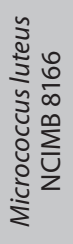 & 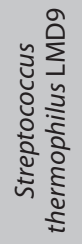 & 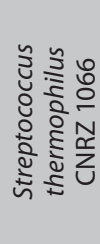 \\
\hline \multicolumn{7}{|c|}{ Ln. mesenteroides } \\
\hline LEY1 & n.d. & n.d. & n.d. & n.d. & n.d. & n.d. \\
\hline LEY2 & n.d. & n.d. & n.d. & n.d. & n.d. & n.d. \\
\hline LEY3 & n.d. & n.d. & n.d. & 9.5 & n.d. & n.d. \\
\hline LEY4 & n.d. & n.d. & n.d. & 9.5 & n.d. & n.d. \\
\hline LEY5 & n.d. & n.d. & n.d. & 8.0 & n.d. & n.d. \\
\hline LEY9 & n.d. & n.d. & n.d. & 9.0 & n.d. & n.d. \\
\hline LEY10 & n.d. & n.d. & n.d. & n.d. & n.d. & n.d. \\
\hline \multicolumn{7}{|c|}{ Lb. rhamnosus } \\
\hline LEY14 & 11.5 & n.d. & n.d. & n.d. & n.d. & n.d. \\
\hline LEY15 & 12.0 & n.d. & n.d. & n.d. & n.d. & n.d. \\
\hline LEY16 & 11.5 & n.d. & n.d. & n.d. & n.d. & n.d. \\
\hline LEY17 & 11.5 & n.d. & n.d. & n.d. & n.d. & n.d. \\
\hline LEY18 & 12.0 & n.d. & n.d. & n.d. & n.d. & n.d. \\
\hline LEY19 & 11.0 & n.d. & n.d. & n.d. & n.d. & n.d. \\
\hline LEY20 & n.d. & n.d. & n.d. & n.d. & n.d. & n.d. \\
\hline \multicolumn{7}{|l|}{ E. hirae } \\
\hline LMA16 & n.d. & n.d. & n.d. & n.d. & n.d. & n.d. \\
\hline LMA18 & n.d. & n.d. & n.d. & n.d. & n.d. & n.d. \\
\hline \multicolumn{7}{|c|}{ E. faecium } \\
\hline LMA1 & 24.0 & 16.5 & 12.0 & n.d. & n.d. & n.d. \\
\hline LMA2 & n.d. & n.d. & n.d. & n.d. & n.d. & n.d. \\
\hline LMA3 & 11.5 & 12.5 & n.d. & n.d. & n.d. & n.d. \\
\hline LMA4 & 11.5 & 11.5 & n.d. & n.d. & 10.0 & n.d. \\
\hline LMA5 & 23.0 & 15.5 & 10.0 & n.d. & 11.0 & n.d. \\
\hline LMA6 & 16.5 & 16.0 & n.d. & n.d. & n.d. & n.d. \\
\hline LMA7 & 15.0 & 15.5 & n.d. & n.d. & 12.0 & n.d. \\
\hline LMA8 & n.d. & n.d. & n.d. & n.d. & n.d. & n.d. \\
\hline LMA9 & n.d. & n.d. & n.d. & n.d. & 10.0 & n.d. \\
\hline LMA10 & n.d. & n.d. & n.d. & n.d. & 10.0 & n.d. \\
\hline LMA11 & 11.5 & 10.0 & n.d. & n.d. & n.d. & n.d. \\
\hline LMA12 & 22.0 & 16.0 & 10.0 & n.d. & n.d. & n.d. \\
\hline LMA13 & n.d. & n.d. & n.d. & n.d. & n.d. & n.d. \\
\hline LMA14 & n.d. & n.d. & n.d. & n.d. & n.d. & n.d. \\
\hline LMA15 & n.d. & n.d. & n.d. & n.d. & n.d. & n.d. \\
\hline LMA17 & n.d. & n.d. & n.d. & n.d. & n.d. & n.d. \\
\hline LMA19 & n.d. & n.d. & n.d. & n.d. & n.d. & n.d. \\
\hline LMA20 & n.d. & n.d. & n.d. & n.d. & n.d. & n.d. \\
\hline LMA21 & n.d. & n.d. & n.d. & n.d. & n.d. & n.d. \\
\hline
\end{tabular}

n.d.=inhibitory activity not detected

\section{Cluster analysis of the isolates}

To typify the isolates and classify them as different strains, all 35 isolates were compared by clustering analysis (UPGMA) using the 39 examined phenotypic traits. Fig. 2 shows the resulting dendrogram. It should be noted that the analysis grouped together all the isolates of the same species. The
Table 6. Biogenic amines detected in different cultures of lactic acid bacteria isolated from Algerian raw camel's milk

\begin{tabular}{|c|c|c|c|c|c|}
\hline \multicolumn{6}{|c|}{$c($ biogenic amine $) / \mathrm{mM}$} \\
\hline 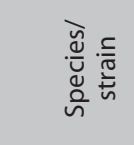 & 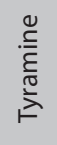 & 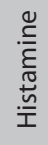 & 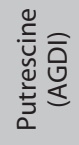 & 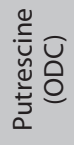 & $\begin{array}{l}\frac{0}{\bar{N}} \\
\frac{\pi}{\pi} \\
\frac{\pi}{0} \\
\tilde{U}\end{array}$ \\
\hline \multicolumn{6}{|c|}{ Ln. mesenteroides } \\
\hline LEY1 & - & - & - & - & - \\
\hline LEY2 & - & - & - & - & - \\
\hline LEY3 & - & - & - & - & - \\
\hline LEY4 & - & - & - & - & - \\
\hline LEY5 & - & - & - & - & - \\
\hline LEY9 & - & - & - & - & - \\
\hline LEY10 & - & - & - & - & - \\
\hline
\end{tabular}

\begin{tabular}{|c|c|c|c|c|c|}
\hline \multicolumn{6}{|c|}{ Lb. rhamnosus } \\
\hline LEY14 & - & - & - & - & - \\
\hline LEY15 & - & - & - & - & - \\
\hline LEY16 & - & - & - & - & - \\
\hline LEY17 & - & - & - & - & - \\
\hline LEY18 & - & - & - & - & - \\
\hline LEY19 & - & - & - & - & - \\
\hline LEY20 & - & - & - & - & - \\
\hline \multicolumn{6}{|l|}{ E. hirae } \\
\hline LMA16 & - & - & - & - & - \\
\hline LMA18 & - & - & - & - & - \\
\hline \multicolumn{6}{|l|}{ E. faecium } \\
\hline LMA1 & + & - & - & - & - \\
\hline LMA2 & + & - & - & - & - \\
\hline LMA3 & + & - & - & - & - \\
\hline LMA4 & + & - & - & - & - \\
\hline LMA4 & + & - & - & - & - \\
\hline LMA6 & + & - & - & - & - \\
\hline LMA7 & + & - & - & - & - \\
\hline LMA8 & + & - & - & - & - \\
\hline LMA9 & + & - & - & - & - \\
\hline LMA10 & + & - & - & - & - \\
\hline LMA11 & + & - & - & - & - \\
\hline LMA12 & + & - & - & - & - \\
\hline LMA13 & + & - & - & - & - \\
\hline LMA14 & + & - & - & - & - \\
\hline LMA15 & + & - & - & - & - \\
\hline LMA17 & + & - & - & - & - \\
\hline LMA19 & + & - & - & - & - \\
\hline LMA20 & + & - & - & - & - \\
\hline LMA21 & + & - & - & - & - \\
\hline
\end{tabular}

$\mathrm{AGDI}=$ agmatine deiminase route, $\mathrm{ODC}=$ ornithine decarboxylase route, + biogenic amine production, - biogenic amine production not detected

results also indicate that all the isolates are different strains, except for Ln. mesenteroides LEY3 and LEY4, which clustered together. These may be understood as isolates of the same strain. The results of the cluster analysis based solely on phenotypic characteristics clearly showed the extent of intraspecies diversity. The wide phenotypic, biochemical and 


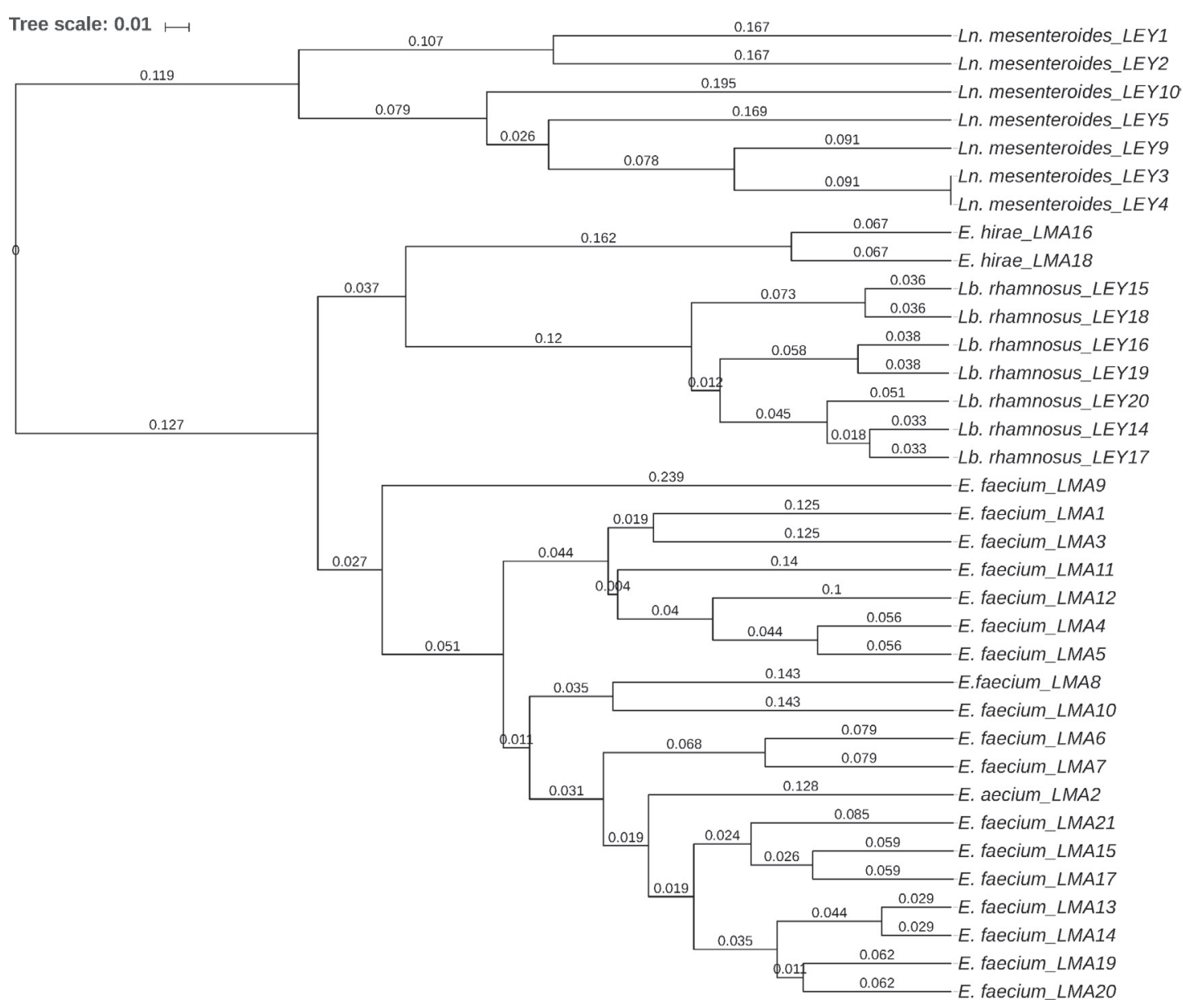

Fig. 2. Dendrogram resulting from cluster analysis based on the 39 examined phenotypic characteristics of the 35 lactic acid bacteria isolates

technological diversity among the isolated strains reflects the diversity of $L A B$ in camel's milk (2). Indeed, it may be an excellent source of $L A B$ with potential applications as adjunct cultures in the dairy industry for camel milk products, and perhaps beyond.

\section{CONCLUSIONS}

Raw camel's milk produced in Algeria is a source of dairy $L A B$ strains that might be used as adjunct cultures for the manufacture of camel, and perhaps other, dairy products. Of particular interest might be Leuconostoc mesenteroides LEY10, which showed good proteolytic activity and produced acetaldehyde and dextran in milk, all the Lactobacillus rhamnosus strains, which produced interesting flavour compounds such as diacetyl and acetoin and showed potential antimicrobial activities and Enterococcus faecium LMA5, which showed the strongest antimicrobial activity of all the isolates. The results of the cluster analysis based on the examined phenotypic characteristics clearly reveal the intraspecies diversity. This method might, therefore, be used for the typification of other isolates when no genetic information is available.

\section{FUNDING AND ACKNOWLEDGMENTS}

This work was funded by the Spanish State Research Agency (AEI) and the European Regional Development Funds (FEDER) (AGL2016-78708-R, AEI/FEDER, UE), by the Plan for Science, Technology and Innovation of the Principality of Asturias 2018-2020, co-financed by FEDER (IDI/2018/000114, FICYT/FEDER, UE), and by the Spanish National Research Council (CSIC201870I091, CSIC). The authors are grateful to Adrian Burton for language assistance.

\section{CONFLICT OF INTEREST}

The authors report no conflict of interest. The authors alone are responsible for the content and writing of the article.

\section{AUTHORS' CONTRIBUTION}

Y. Saidi performed data collection and analysis, analysis and interpretation of results and drafted the manuscript. B. del Rio was involved in design and conception of the work, performed data analysis and interpretation, drafted the 
manuscript, and made a critical revision of the manuscript. D.E. Senouci performed data collection and analysis. B. Redruello performed analysis. B. Martinez provided material and performed data analysis and made a critical revision of the manuscript. V. Ladero designed the work, drafted and made a critical revision of the manuscript. M. Kihal designed the work and made critical revision of the results. M.A. Alvarez was involved in the conception of the work, drafted and made critical revision of the manuscript. All authors read and approved the final version to be published.

\section{ORCID ID}

Y. Saidi (๑) https://orcid.org/0000-0001-5204-8522

B. del Rio (1) https://orcid.org/0000-0001-8107-1975

D. E. Senouci 은ttps://orcid.org/0000-0003-4784-7252

B. Redruello 1 https://orcid.org/0000-0003-1787-5594

B. Martinez 이 https://orcid.org/0000-0001-7692-1963

V. Ladero ㄴ https://orcid.org/0000-0002-7613-3745

M. Kihal (D) https://orcid.org/0000-0003-2901-373X

M. A. Alvarez 10 https://orcid.org/0000-0001-9607-7480

\section{REFERENCES}

1. Boudjenah-Haroun, Laleye S, Chahra LCS, Farida MM, Saliha SA, Abderrahmane M. Coagulation of camel milk using dromedary gastric enzymes as a substitute of the commercial rennet. Am J Food Technol. 2012;7(7):409-19.

https://doi.org/10.3923/ajft.2012.409.419

2. Khedid K, Faid M, Mokhtari A, Soulaymani A, Zinedine A. Characterization of lactic acid bacteria isolated from the one humped camel milk produced in Morocco. Microbiol Res 2009;164(1):81-91.

https://doi.org/10.1016/j.micres.2006.10.008

3. Capozzi V, Fragasso M, Russo P. Microbiological safety and the management of microbial resources in artisanal foods and beverages: The need for a transdisciplinary assessment to conciliate actual trends and risks avoidance. Microorganisms. 2020;8(2):306.

https://doi.org/10.3390/microorganisms8020306

4. Settanni L, Moschetti G. Non-starter lactic acid bacteria used to improve cheese quality and provide health benefits. Food Microbiol. 2010;27(6):691-7.

https://doi.org/10.1016/j.fm.2010.05.023

5. Leroy F, De Vuyst L. Lactic acid bacteria as functional starter cultures for the food fermentation industry. Trends Food Sci Technol. 2004;15(2):67-78.

https://doi.org/10.1016/j.tifs.2003.09.004

6. Linares DM, del Río B, Ladero V, Martínez N, Fernández M, Martín MC, Álvarez MA. Factors influencing biogenic amines accumulation in dairy products. Front Microbiol. 2012;3:180. https://doi.org/10.3389/fmicb.2012.00180

7. Ladero V, Martín MC, Redruello B, Mayo B, Flórez AB, Fernández M, Álvarez MA. Genetic and functional analysis of biogenic amine production capacity among starter and non-starter lactic acid bacteria isolated from artisanal cheeses. Eur Food Res Technol. 2015;241(3):377-83.

https://doi.org/10.1007/s00217-015-2469-z

8. Ladero V, Linares DM, Pérez M, del Rio B, Fernández M, Alvarez MA. Biogenic amines in dairy products. In: Tamime AY, editor. Microbial toxins in dairy products. New Jersey, USA: Wiley; 2016. pp. 94-131.

https://doi.org/10.1002/9781118823095.ch4

9. Hayward AC. Detection of gas production from glucose by heterofermentative lactic acid bacteria. J Gen Microbiol. 1957;16(1):9-15.

https://doi.org/10.1099/00221287-16-1-9

10. Thomas T. Agar medium for differentiation of Streptococcus cremoris from the other bacteria. NZJ Dairy Sci Technol. 1973;8:70-1.

11. Weisburg WG, Barns SM, Pelletier DA, Lane DJ. 16S ribosomal DNA amplification for phylogenetic study. J Bacteriol. 1991;173(2):697-703.

https://doi.org/10.1128/jb.173.2.697-703.1991

12. Alegría Á, Delgado S, Flórez AB, Mayo B. Identification, typing, and functional characterization of Leuconostoc spp. strains from traditional, starter-free cheeses. Dairy Sci Technol. 2013;93(6):657-73.

https://doi.org/10.1007/s13594-013-0128-3

13. Altschul SF, Madden TL, Schäffer AA, Zhang J, Zhang Z, Miller W, Lipman DJ. Gapped BLAST and PSI-BLAST: A new generation of protein database search programs. Nucleic Acids Res. 1997;25(17):3389-402.

https://doi.org/10.1093/nar/25.17.3389

14. Poyart C, Quesnes G, Trieu-Cuot P. Sequencing the gene encoding manganese-dependent superoxide dismutase for rapid species identification of enterococci. J Clin Microbiol. 2000;38(1):415-8.

15. Gasson MJ. Plasmid complements of Streptococcus lactis NCDO 712 and other lactic streptococci after protoplast-induced curing. J Bacteriol. 1983;154(1):1-9.

https://doi.org/10.1128/JB.154.1.1-9.1983

16. Kempler GM, McKay LL. Improved medium for detection of citrate-fermenting Streptococcus lactis subsp. diacetylactis. Appl Environ Microbiol. 1980;39(4):926-7. https://doi.org/10.1128/AEM.39.4.926-927.1980

17. Salazar N, Gueimonde M, Hernández-Barranco AM, Ruas-Madiedo P, de los Reyes-Gavilán CG. Exopolysaccharides produced by intestinal Bifidobacterium strains act as fermentable substrates for human intestinal bacteria. Appl Environ Microbiol. 2008;74(15):4737-45.

https://doi.org/10.1128/AEM.00325-08

18. Schillinger U, Lücke FK. Antibacterial activity of Lactobacillus sake isolated from meat. Appl Environ Microbiol. 1989;55(8):1901-6.

https://doi.org/10.1128/AEM.55.8.1901-1906.1989 
19. Redruello B, Ladero V, Cuesta I, Álvarez-Buylla JR, Martín MC, Fernández M, Alvarez MA. A fast, reliable, ultra high performance liquid chromatography method for the simultaneous determination of amino acids, biogenic amines and ammonium ions in cheese, using diethyl ethoxymethylenemalonate as a derivatising agent. Food Chem. 2013;139(1-4):1029-35.

https://doi.org/10.1016/j.foodchem.2013.01.071

20. Empower software v. 2.0, Waters Corporation, Milford, MA, USA; 2020. Available from: https://www.waters.com/ waters/en_US/Waters-Software-Services-and-Support.

21. Garcia-Vallvé S, Palau J, Romeu A. Horizontal gene transfer in glycosyl hydrolases inferred from codon usage in Escherichia coli and Bacillus subtilis. Mol Biol Evol 1999;16(9):1125-34.

https://doi.org/10.1093/oxfordjournals.molbev.a026203

22. Letunic I, Bork P. Interactive tree of life (iTOL) v3: An online tool for the display and annotation of phylogenetic and other trees. Nucleic Acids Res. 2016;44(W1):W242-5.

https://doi.org/10.1093/nar/gkw290

23. Ogier JC, Casalta E, Farrokh C, Saïhi A. Safety assessment of dairy microorganisms: The Leuconostoc genus. Int J Food Microbiol. 2008;126(3):286-90.

https://doi.org/10.1016/j.ijfoodmicro.2007.08.012

24. Zarour K, Benmechernene Z, Hadadji M, Moussa-Boudjemaa B, Henni JE, Kihal M. Microbiological and technological characterisation of Leuconostoc mesenteroides sp. isolated from raw goat's and Algerian camel's milk. Nat Technol. 2013;(8):3947 (in French).

25. Aguilar-Galvez A, Dubois-Dauphin R, Destain J, Campos D, Thonart P. Enterococci: Advantages and disadvantages in biotechnology (a review). Biotechnol Agron Soc Environ. 2012;16(1):67-76 (in French).

26. Ismaili MA, Guilal J, Hamama A, Saidi B, Zahar M. Identification of lactic acid bacteria from raw camel's milk from the south of Morocco.Int J Multi Sci. 2016;1(1):81-94 (in French).

27. Leboš Pavunc A, Beganović J, Kos B, Uroić K, Blažić M, Šušković J. Characterization and application of autochthonous starter cultures for fresh cheese production. Food Technol Biotechnol. 2012;50(2):141-51.

28. Nieto-Arribas P, Seseña S, Poveda JM, Chicón R, Cabezas L, Palop L. Enterococcus populations in artisanal Manchego cheese: Biodiversity, technological and safety aspects. Food Microbiol. 2011;28(5):891-9.

https://doi.org/10.1016/j.fm.2010.12.005

29. Franz CM, Holzapfel WH, Stiles ME. Enterococci at the crossroads of food safety? Int J Food Microbiol. 1999;47(1-2):1-24. https://doi.org/10.1016/S0168-1605(99)00007-0

30. Ayad EHE, Nashat S, El-Sadek N, Metwaly H, El-Soda M. Selection of wild lactic acid bacteria isolated from traditional Egyptian dairy products according to production and technological criteria. Food Microbiol. 2004;21(6):715-25.

https://doi.org/10.1016/j.fm.2004.02.009
31. Widyastuti $Y$, Rohmatussolihat, Febrisiantosa A. The role of lactic acid bacteria in milk fermentation. Food Nutr Sci. 2014;5(4):435-42.

http://doi.org/10.4236/fns.2014.54051

32. Zhang S, Zhang L, Jiao Y, Luo X, Li H, Xin L, et al. Technological characterization of lactic acid bacteria protease isolated from traditional chinese fermented milk. J Food Qual. 2014;37(6):395-402.

https://doi.org/10.1111/jfq.12115

33. Giraffa G, Paris A, Valcavi L, Gatti M, Neviani E. Genotypic and phenotypic heterogeneity of Streptococcus thermophilus strains isolated from dairy products. J Appl Microbiol. 2001;91(5):937-43.

https://doi.org/10.1046/j.1365-2672.2001.01464.x

34. Domingos-Lopes MFP, Stanton C, Ross PR, Dapkevicius MLE, Silva CCG. Genetic diversity, safety and technological characterization of lactic acid bacteria isolated from artisanal Pico cheese. Food Microbiol. 2017;63:178-90.

https://doi.org/10.1016/j.fm.2016.11.014

35. Ayad EHE, Verheul A, Engels WJM, Wouters JTM, Smit G. Enhanced flavour formation by combination of selected lactococci from industrial and artisanal origin with focus on completion of a metabolic pathway. J Appl Microbiol. 2001;90(1):59-67.

https://doi.org/10.1046/j.1365-2672.2001.01219.x

36. Franciosi E, Settanni L, Cavazza A, Poznanski E. Biodiversity and technological potential of wild lactic acid bacteria from raw cows' milk. Int Dairy J. 2009;19(1):3-11.

https://doi.org/10.1016/j.idairyj.2008.07.008

37. Kongo JM. Lactic acid bacteria as starter-cultures for cheese processing: past, present and future developments. In: Kongo JM, editor. Lactic acid bacteria-R \& D for food, health and livestock purposes. London, UK: IntechOpen. 2013. pp. 3-22.

https://doi.org/10.5772/55937

38. Pisano MB, Fadda ME, Melis R, Ciusa ML, Viale S, Deplano M, Cosentino $S$. Molecular identification of bacteriocins produced by Lactococcus lactis dairy strains and their technological and genotypic characterization. Food Control. 2015;51:1-8.

https://doi.org/10.1016/j.foodcont.2014.11.005

39. Caplice E, Fitzgerald GF. Food fermentations: Role of microorganisms in food production and preservation. Int J Food Microbiol. 1999;50(1-2):131-49.

https://doi.org/10.1016/S0168-1605(99)00082-3

40. Badis A, Laouabdia-Sellami N, Guetarni D, Kihal M, Ouzrout R. Phenotypic characterisation of lactic acid bacteria isolated from raw goat's milk of two local caprine populations Arabia and Kabyle. Sci Tech. 2005;23:30-37 (in French).

41. Benhouna IS, Heumann A, Rieu A, Guzzo J, Kihal M, Bettache $\mathrm{G}$, et al. Exopolysaccharide produced by Weissella confusa: Chemical characterisation, rheology and bioactivity. 
Int Dairy J. 2019;90:88-94.

https://doi.org/10.1016/j.idairyj.2018.11.006

42. Smit G, Smit BA, Engels WJM. Flavour formation by lactic acid bacteria and biochemical flavour profiling of cheese products. FEMS Microbiol Rev. 2005;29(3):591-610.

https://doi.org/10.1016/j.fmrre.2005.04.002

43. Sánchez Jl, Martínez B, Rodríguez A. Rational selection of Leuconostoc strains for mixed starters based on the physiological biodiversity found in raw milk fermentations. Int J Food Microbiol. 2005;105(3):377-87.

https://doi.org/10.1016/j.ijfoodmicro.2005.04.025

44. Pogačić T, Maillard MB, Leclerc A, Hervé C, Chuat V, Valence $F$, Thierry A. Lactobacillus and Leuconostoc volatilomes in cheese conditions. Appl Microbiol Biotechnol. 2016;100(5):2335-46. https://doi.org/10.1007/s00253-015-7227-4

45. Senouci DE, Yasmine S, Fatima G, Amina Z, Battache G, Mebrouk K. Antifungal and antibacterial activity of some lactobacilli isolated from camel's milk biotope in the south of algeria. J Microbiol Biotechnol Food Sci. 2018/19;8(3):871.

https://doi.org/10.15414/jmbfs.2018-19.8.3.871-877

46. Benmechernene Z, Fernandez-No I, Kihal M, Bohme K, Calo-Mata P, Barros-Velazquez J. Recent patents on bacteriocins: Food and biomedical applications. Recent Patents DNA Gene Seq. 2013;7(1):66-73.

https://doi.org/10.2174/1872215611307010010

47. EFSA Panel on Biological Hazards (BIOHAZ). Scientific opinion on risk based control of biogenic amine formation in fermented foods. EFSA J. 2011;9(10):2393.

https://doi.org/10.2903/j.efsa.2011.2393

48. Ladero V, Fernández M, Calles-Enríquez M, Sánchez-Llana E, Cañedo E, Martín MC, Alvarez MA. Is the production of the biogenic amines tyramine and putrescine a species-level trait in enterococci? Food Microbiol. 2012;30(1):132-8. https://doi.org/10.1016/j.fm.2011.12.016

49. Capozzi V, Fragasso M, Romaniello R, Berbegal C, Russo P, Spano G. Spontaneous food fermentations and potential risks for human health. Fermentation. 2017;3(4):49. https://doi.org/10.3390/fermentation3040049 